\title{
SISTEM BAGI HASIL PETANI PENYAKAP DI DESA KRAI KECAMATAN YOSOWILANGUN KABUPATEN LUMAJANG
}

\author{
Mochammad Kamil Malik ${ }^{1}$, Sri Wahyuni ${ }^{1}$, Joko Widodo ${ }^{1}$ \\ ${ }^{1}$ Program Studi Pendidikan, Fakultas Keguruan dan Ilmu Pendidikan, Universitas Jember \\ e-mail: sriwahyunipe.fkip@unej.ac.id
}

\begin{abstract}
Abstrak
Sektor pertanian sangat berperan dalam penyerapan tenaga kerja di pedesaan, terutama bagi masyarakat yang berpendidikan rendah. Sehingga sebagian besar masyarakat pedesaan bekerja di sektor pertanian. Pertanian merupakan salah satu bentuk usaha yang dilakukan oleh masyarakat, terutama masyarakat pedesaan dengan memanfatkan sumber daya modal dan sumber daya alam yang ada seperti tanah dan air. Masyarakat pedesaan yang bekerja di sektor pertanian terbagi dalam beberapa macam status yaitu petani pemilik, buruh tani, petani penyakap (bagi hasil), dan petani penyewa. Sesuai dengan pendapat Soelaeman (2006:132), masyarakat pedesaan ditentukan oleh basis fisik dan sosialnya, seperti ada kolektivitas, petani individu, tuan tanah, buruh tani, pemaro, penyewa dan lain-lain.Tujuan penelitian ini adalah untuk mengetahui system bagi hasil petani penyakap di Desa Krai Kecamatan Yosowilangun Kabupaten Lumajang. Jenis penelitian ini adalah penelitian deskriptif dengan pendekatan kualitatif. Tempat penelitian ditentukan dengan menggunakan metode Purposive. Teknik pengumpulan data dalam penelitian ini menggunakan metode wawancara, dokumentasi dan observasi. Analisis data dengan cara reduksi data, penyajian data, dan penarikan kesimpulan. Hasil penelitian menunjukkan bahwa sitem bagi hasil yang ada di Desa Krai ini menganut sistem bagi Berdasarkan hasil penelitian dan pembahasan mengenai sistem bagi hasil di desa Krai Yosowilangun Kabupaten Lumajang dapat disimpulkan bahwa sistem bagi hasil masih bersifat tradisional dan sederhana. Sistem bagi hasil merupakan salah satu bentuk dari perjanjian tidak tertulis yang sifatnya cenderung seadanya sesuai dengan adat kebiasaan.
\end{abstract}

Kata Kunci: Sistem bagi hasil, petani penyakap

\section{PENDAHULUAN}

Sektor pertanian sangat berperan dalam penyerapan tenaga kerja di pedesaan, terutama bagi masyarakat yang berpendidikan rendah. Sehingga sebagian besar masyarakat pedesaan bekerja di sektor pertanian. Pertanian merupakan salah satu bentuk usaha yang dilakukan oleh masyarakat, terutama masyarakat pedesaan dengan memanfatkan sumber daya modal dan sumber daya alam yang ada seperti: tanah dan air. Masyarakat pedesaan yang bekerja di sektor pertanian terbagi dalam beberapa macam status yaitu petani pemilik, buruh tani, petani penyakap (bagi hasil), dan petani penyewa. Sesuai dengan pendapat Soelaeman (2006:132), masyarakat pedesaan ditentukan oleh basis fisik dan sosialnya, seperti ada kolektivitas, petani individu, tuan tanah, buruh tani, pemaro, penyewa dan lain-lain.

Dari beberapa macam petani tersebut, penelitian ini hanya memfokuskan pada petani penyakap, karena tidak semua petani di pedesaan memiliki lahan pertanian sendiri. Seperti halnya masyarakat di desa Krai yang berada di Kecamatan Yosowilangun, Kabupaten Lumanajang yang tidak semuanya memiliki lahan pertanian namun mereka berusaha menggarap lahan milik orang lain dengan sistem bagi hasil atau sebagai petani penyakap.

Petani penyakap merupakan petani yang tidak memiliki lahan pertanian tetapi menggarap tanah garapan dengan sistem bagi hasil. Menurut Raharjo (2004:144), penyakapan atau sistem bagi hasil adalah suatu bentuk ikatan ekonomi-sosial, dalam mana si pemilik tanah menyerahkan tanahnya untuk digarap orang lain (petani penyakap) dengan persyaratan-persyaratan yang disetujui bersama.

Kehidupan petani penyakap selalu bekerja sama dengan petani pemilik lahan karena keduanya saling membutuhkan. Petani penyakap membutuhkan lahan pertanian dari petani pemilik lahan, 
sedangkan petani pemilik lahan membutuhkan penyakap untuk menggarap lahan yang tidak sanggup digarap sendiri. Semakin banyak petani pemilik lahan yang memberikan kepercayan kepada petani penyakap untuk menggarap lahan miliknya, maka semakian besar harapan para petani penyakap untuk bekerja dan mendapatkan penghasilan.

Sesuai dengan penjelasan di atas, yang menarik dari petani penyakap di desa Krai yaitu mereka berusaha menggarap lahan yang bukan miliknya sendiri dengan resiko yang harus mereka tanggung sendiri sesuai dengan aturan dalam sistem "bagi hasil". Lahan yang digarap petani penyakap merupakan lahan yang kondisinya tidak seperti lahan pertanian di daerah lain yang lancar pengairannya melainkan lahan dengan ketersediaan air yang terbatas terutama pada saat musim kemarau. Petani penyakap tidak bisa menanam padi sepanjang tahun, melainkan hanya pada saat musim penghujan saja. Sedangkan pada musim kemarau, petani penyakap hanya bisa menanam palawija seperti kedelai dan jagung. Padahal hasil dari menanam padi lebih besar jika dibandingkan dengan hasil palawija. Petani penyakap tidak bisa memperoleh hasil yang maksimal dalam menggarap lahan milik orang lain.

Sedangkan isi perjanjian yang meliputi hak dan kewajiban masing - masing pihak juga ditentukan oleh mereka sendiri. System bagi hasil yang telah disepakati oleh petani penyakap dan petani pemilik lahan nantinya hasil akan dibagi sesuai kesepakatan yang telah disepakati bersama, umumnya dengan pembagian hasil yang ditetapkan. System bagi hasil yang ada di wilayah desa Krai kecamatan Yosowilangun Kabupaten Lumajang masih menggunakan system bagi hasil tradisional yaitu sistem bagi hasil martelu, sepuluh loro dan pitu loro.

\section{METODE}

Metode penentuan lokasi atau tempat penelitian ditentukan dengan metode purposive area yaitu, desa Krai kecamatan Yosowilangun kabupaten Lumajang. Penentuan informan penelitian ini ditentukan. Informan utama dalam penelitian ini adalah petani penyakap di desa Krai. Informan pendukung dalam penelitian ini adalah petani pemilik lahan di desa Krai yang tanahnya digarap oleh petani penyakap. Metode yang digunakan untuk pengumpulan data terdiri dari: metode observasi yang digunakan untuk memperoleh informasi yang sesuai dengan tujuan penelitian, melalui pengamatan secara langsung fenomena yang terjadi di tempat penelitian untuk mendapatkan data sekunder yang nantinya menjadi data pendukung dari wawancara. Metode wawancara dilakukan untuk mendapatkan data primer atau data utama, yaitu berkaitan dengan sistem bagi hasil yang ada di desa Krai. Metode dokumen dilakukan untuk mendapatkan data profil desa Krai, foto yang berkaitan dengan sistem bagi hasil petani penyakap.

Analisis data menggunakan analisis data kualitatif yang terdiri dari reduksi data dilakukan dengan mengidentifikasi data yang terkumpul, kemudian memilah-milah data tersebut sesuai dengan fokus penelitian. Penyajian data merupakan upaya penyajian data agar membentuk sekumpulan informasi yang tersusun secara terorganisir, sehingga mempermudah memahami tentang apa yang ditemukan dilapangan pada saat penelitian. Data tersebut disajikan dalam bentuk tabel dan teks naratif yang disusun secara sistematis. Penarikan kesimpulan dalam penelitian ini dilakukan dalam bentuk paparan deskriptif tentang sistem bagi hasil petani penyakap di desa Krai, Kecamatan Yosowilangun, Kabupaten Lumajang, yang sebelumnya dituliskan dalam rumusan masalah penelitian.

\section{HASIL DAN PEMBAHASAN}

Dari hasil observasi, wawancara, dan dokumen maka dapat diperoleh informasi tentang sistem bagi hasil petani penyakap di Desa Krai Kecamatan Yosowilangun Kabupaten Lumajang adalah sebagai berikut: 
Pelaksanaan dan Isi Perjanjian Sistem Bagi Hasil

Keberadaan hukum kebiasaan dalam masyarakat merupakan suatu fenomena yang cenderung pasti ada. Hal ini dikarenakan hukum merupakan salah satu alat atau tolok ukur masyarakat dalam berproses dalam kehidupan sehari-hari. Oleh karena itu dalam suatu kehidupan di masyarakat pasti ada yang namanya hukum. Entah itu hukum adat/kebiasaan yang tidak tertulis bahkan hingga hukum positif yang tertulis.

a. Latar Belakang Perjanjian Bagi Hasil antara Pemilik Sawah dengan Buruh Tani Penggarap di Desa Krai Kecamatan Yosowilangun Kabupaten Lumajang

Sistem hukum Indonesia yang bersifat tradisional pada umumnya memuat hukum tidak tertulis yang tidak dibukukan ke dalam undang-undang tertulis. Hukum seperti itu dalam kehidupan masyarakat disebut dengan hukum adat atau hukum kebiasaan. Meskipun tidak tertulis, hukum kebiasaan itu berlaku secara umum dan ditaati oleh semua anggota masyarakat secara suka rela dan dikontrol secara langsung oleh lingkungan. Karakter hukum seperti ini identik dengan masyarakat pedesaan. Menurut penulis, hukum kebiasaan yang seperti ini akan tetap ada dan terus berlangsung selama tanah pertanian itu masih ada.

Menurut pendapat para buruh tani di desa Krai kecamatan Yosowilangun kabupaten Lumajang, perjanjian bagi hasil merupakan perjanjian antara pemilik sawah dengan petani penyakap yang wujudnya tidak tertulis namun bisa disepakati bersama. Perjanjian bagi hasil didasarkan atas rasa kepercayaan di antara kedua pihak yang mana pemilik sawah menginginkan petani penyakap mulai dari mengolah hingga memetik hasilnya dengan pembagian berdasarkan kesepakatan yang sesuai dengan hukum kebiasaan yang berlaku.

Sistem bagi hasil yang berkembang hingga saat ini juga berfungsi sebagai sarana pemeliharaan hubungan baik sesama keluarga dekat. Pemilik sawah sebelum menawarkan bagi hasil kepada orang lain terlebih dahulu ditawarkan kepada sanak keluarga yang tidak punya sawah. Kalau tidak bersedia baru ditawarkan ke orang lain. Perjanjian bagi hasil yang ada di desa Krai kecamatan Yosowilangun kabupaten Lumajang masih lebih diprioritaskan untuk keluarga dekat, setelah itu baru tetangga dekat atau orang lain.

Latar belakang pemilik sawah melakukan transaksi bagi hasil dikarenakan berbagai alasan seperti pemilik sawah kurang mampu menggarap sawah miliknya, faktor usia, punya pekerjaan lain, atau ada juga karena sawahnya jauh dari tempat tinggal. Apabila sawahnya tidak dikerjakan oleh orang lain maka tidak menutup kemungkinan akan menjadi tanah yang tidak tergarap sehingga tingkat produktivitasnya turun. Alasan para buruh tani penggarap sawah menerima perjanjian bagi hasil adalah karena tidak punya lahan sendiri dan tidak memiliki pekerjaan yang layak. Hal ini sejalan dengan pendapat Syamsuri (2012) yang menyatakan bahwa yang berhak mengadakan perjanjian tersebut menurut hukumnya yang berlaku sekarang ini tidak saja terbatas pada orang-orang tertentu saja.

b. Bentuk Pelaksanaan Perjanjian Sistem Bagi Hasil Penggarap

Perjanjian bagi hasil merupakan salah satu bentuk produk hukum kebiasaan yang berlaku dalam kehidupan masayarakat desa Krai kecamatan Yosowilangun kabupaten Lumajang. Meskipun hal tersebut tidak tertulis, kepastian hukumnya tidak dapat diremehkan begitu saja. Hukum kebiasaan tersebut merupakan serangkaian proses hukum dengan tujuan ketercapaian kesepakatan. Pelaksanaan hukum kebiasaan tersebut tidak akan pernah mati selama masyarakatnya masih punya ruang kontrol sepanjang proses kehidupan berlangsung.

Perjanjian bagi hasil merupakan hukum yang dilaksanakan secara lisan meskipun sebenarnya sudah ada produk hukum tertulis yang telah dimuat di dalam UU No. 2 Tahun 1960 tentang Perjanjian Bagi Hasil. Akan tetapi pada kenyataannya, masyarakat hampir tidak ada yang mengetahui isi undangundang tersebut. Padahal menurut pasal 3 ayat (1) dalam undang-undang tersebut menyebutkan secara 
jelas bahwa perjanjian bagi hasil dibuat secara tertulis antara pihak-pihak terkait di hadapan kepala desa setempat. Akan tetapi undang-undang itu tidak ada yang menerapkannya di dalam kehidupan masyarakat buruh tani di sana. Kesepakatan lisan sudah mampu diaplikasikan tanpa ada masalah hingga saat ini.

Bentuk perjanjian yang telah disebutkan di atas menerangkan bahwa hukum kebiasaan seperti perjanjian bagi hasil yang berkembang di masayarakat desa Krai kecamatan Yosowilangun kabupaten Lumajang bersifat sederhana. Hal itu bisa dilihat dari proses terjadinya transaksi yang disepakati tanpa melalui proses panjang seperti surat menyurat. Meskipun demikian pelaksanaannya mudah dipahami dan dilaksanakan dengan prinsip saling percaya.

c. Isi Perjanjian Sistem Bagi Hasil

Pembahasan selanjutnya adalah terkait isi dari perjanjian bagi hasil yang ada di lingkungan masyarakat tani di desa Krai kecamatan Yosowilangun kabupaten Lumajang. Isi perjanjiannya berkaitan dengan hak dan kewajiban masing-masing pihak, risiko, jangka waktu perjanjian, serta pembagian hasil panen.

1. Hak dan kewajiban masing-masing pihak

Hak dan kewajiban di antara dua pihak adalah berbeda. Perbedaannya adalah hak pemilik sawah atas perjanjian bagi hasil adalah pasrahan sedangkan hak yang diterima oleh petani penyakap adalah bawon. Sedangkan untuk kewajiban masing masing adalah untuk pemilik sawah, mereka harus menyediakan lahan yang sudah siap untuk ditanami, menyediakan bibit, dan mengerjakan pemupukan tanaman. Kewajiban yang harus dilakukan oleh petani penyakap adalah mengerjakan seluruh proses penanaman hingga panen, selain yang menjadi tugas dari pemilik sawah.

2. Risiko

Kesepakatan atau perjanjian pasti memiliki risiko. Begitu juga dengan perjanjian bagi hasil antara petani pemilik sawah dan buruh tani penggarap sawah. Risiko itu sendiri bisa terjadi pada saat tanaman mengalami gangguan seperti diserang hama, iklim yang ekstrim, serta faktor bencana alam. Beberapa hal tersebut akan mengakibatkan hasil panen mengalami penurunan atau bahkan gagal panen. Semua risiko dalam pelaksanaan perjanjian bagi hasil adalah ditanggung bersama. Berapapun hasil panennya akan tetap dilaksanakan pembagiannya sesuai dengan perjanjian yang telah disepakati.

3. Jangka waktu perjanjian

Jangka waktu pelaksanaan perjanjian bagi hasil pada umumnya tidak ditentukan lama waktunya. Namun ada juga yang dibatasi berdasarkan tahun atau berapa kali masa panen.

4. Pembagian hasil panen

Pembagian hasil panen yang diterima oleh masing-masing pihak yang banyak ditemui adalah perbandingan songo loro dan sepuluh loro. Untuk besaran songo loro, bawon yang diterima oleh buruh tani adala sebesar 2 dan pasrahan milik pemilik sawah adalah sebesar 7. Sedangkan untuk yang besaran sepuluh loro besarnya bawon adalah 2 sedangkan pasrahannya adalah sebesar 8. Jika ada yang penanamannya adalah di lahan kering maka pembagiannya adalah mertelu atau bahkan paron. Jika mertelu maka 1 untuk bawon dan 3 adalah pasrahan, sedangkan untuk paron 1 adalah untuk bawon dan 2 adalah untuk pasrahan

Pertanian merupakan salah satu mata pencaharian utama yang ada di desa Desa Krai Kecamatan Yosowilangun Kabupaten Lumajang. Masyarakat pedesaan sebagian besar bekerja di sektor pertanian untuk memenuhi kebutuhan hidupnya, namun untuk dapat bekerja di bidang pertanian tentu harus memiliki lahan pertanian atau lahan persawahan yang bisa diolah. Bagi masyarakat yang tidak memiliki lahan pertanian, mereka juga dapat bekerja di bidang pertanian dengan menggarap lahan milik orang 
lain dengan sistem bagi hasil atau penyakapan, seperti halnya petani penyakap di Desa Krai yang tidak memiliki lahan, namun mereka memiliki kemauan keras untuk bekerja menggarap lahan milik orang lain dengan sistem bagi hasil.

Penyakap merupakan petani yang tidak memiliki lahan pertanian tetapi menguasai tanah garapan dengan sistem bagi hasil. Menurut Raharjo, 2004:144, penyakapan atau sistem bagi hasil adalah suatu bentuk ikatan ekonomi-sosial, dalam mana si pemilik tanah menyerahkan tanahnya untuk digarap orang lain (penyakap) dengan persyaratan-persyaratan yang disetujui bersama. Bentuk umum pembagian hasil ini antara lain maro, mertelu, dan mrapat. Bagi hasil yang nyata terjadi di masyarakaat adalah mertelu, karena sistem ini yang dianggap paling mudah dalam pembagian biaya produksi dan pembagian hasil panen.Sistem bagi hasil ini, petani penyakap yang menyediakan semua biaya produksi sedangkan petani pemilik lahan hanya menyediakan lahan garapan, sehingga tidak harus membagi biaya produksi antara petani pemilik lahan dengan petani penyakap.

Dalam kehidupan dimasyarakat segala perjanjian dibuat dalam semangat kerukunan antar sesama warga masyarakat. Begitu juga jika seorang Pemilik Tanah yang mempunyai Tanah/Lahan Pertanian yang sangat luas maka akan memberikan suatu kesempatan kepada orang lain yang tidak mempunyai tanah garapan untuk mengerjakan tanahnya yang didasarkan dengan rasa kekeluargaan.

Hal-hal yang menjadi Latar belakang dari pada Perjanjian Bagi Hasil Pertanian di Desa Krai ini adalah: ${ }^{1}$

1. Kalau dari pihak Pemilik tanah sendiri, Biasanya

- Tidak berkesempatan mengerjakan tanahnya sendiri.

- Rasa kekeluargaan.

- Tidak mampu mengerjakan tanah sendiri.

- Keinginan untuk mendapatkan hasil tanpa susah payah.

2. Sedangkan dari Petani Penggarap

- Rasa kekeluargaan.

- Tidak mempunyai tanah garapan.

- Untuk mendapatkan tambahan pendapatan.

Pembagian dan penguasaan lahan pertanian di pedesaan tidak sama antara petani satu dengan petani yang lain. Ada petani yang berlahan luas, petani berlahan sempit, dan ada petani yang tidak memiliki lahan atau buruh tani. Menurut Raharjo (2004: 109), bahwa desa dengan tipe dua kelas secara garis besar digambarkan sebagai desa yang didalamnya terdapat sejumlah kecil warga yang memiliki lahan yang amat luas, dan selebihnya dalam jumlah besar merupakan warga yang tidak memiliki lahan pertanian. Masyarakat yang tidak memiliki lahan pertanian namun berkeinginan untuk bekerja pada sektor pertanian harus berusaha keras untuk tetap betahan hidup dengan menjadi penyakap pada petani yang memilki lahan luas.

Isi dari Perjanjian Bagi Hasil sendiri, hanyalah mengatur sedikit hak dan kewajiban para pihak. Hak dari pemilik lahan pertanian dan petani penggarap hanyalah hasil dari lahan pertanian (sawah) tersebut dalam bentuk gabah. Sedangkan kewajiban dari pemilik lahan, hanya memberikan kuasa kepada petani penggarap untuk mengelolah lahan pertanian (sawah) miliknya dan menanggung biaya-biaya yang disepakati bersama. Kewajiban petani penggarap sendiri adalah mengelolah lahan sawah yang dikuasakan oleh pemilik lahan sawah kepadanya serta mengeluarkan biaya-biaya yang telah disepakatinya bersama pihak pemilik lahan sawah.

Biaya-biaya yang timbul tersebut antara lain:

1. Biaya benih padi 
2. Biaya pupuk

3. Biaya penyewaan traktor

4. Biaya pengairan sawah (irigasi)

Dari biaya-biaya tersebut timbul di atas, pada kenyataannya biaya yang ditanggung oleh petani penggarap lebih banyak dibandingkan dengan biaya yang ditanggung oleh pemilik lahan. Bahkan tidak sedikit lahan yang keseluruhan biaya penggarapannya ditanggung oleh petani penggarapnya.

Petani Penggarap sudah diuntungkan oleh karena mereka diberikan kesempatan oleh pemilik lahan untuk menggarap lahan/sawah walaupun ia tidak memiliki lahan /sawah begitupun sebaliknya pemilik lahan juga di untungkan karena dapat memperoleh hasil dari lahan miliknya tanpa harus bersusah payah menggarap/mengelolah lahan tersebut. Namun pada kenyataannya, petani penggarap mengalami kerugian terutama pada saat menurunnya hasil panen dari lahan sawah yang Ia garap, dikarenakan mayoritas biaya-biaya yang timbul selama masa penggapan ditanggung oleh pihak petani penggarap

Dari hasil penelitian yang dilakukan pelaksanaan Perjanjian Bagi Hasil tanah pertanian di Desa Krai Kecamatan Yosowilangun Kabupaten Lumajang yang penulis ambil sebagai sampel, semua petani di Desa Krai tersebut tidak menentukan atau menggunakan ketentuan yang mengatur mengenai jangka waktu berlangsungnya Perjanjian Bagi Hasil pertanian tersebut. Namun mengenai jangka waktu ini akan disesuaikan menurut kebiasaan yang berlaku ditempat tersebut. Jangka waktu perjanjian yang dilaksanakan di Desa Krai biasanya tidak ditentukan diawal perjanjian tetapi akan di bahas setelah masa panen selesai karena yang dapat menentukan jangka waktu itu hanya pemilik tanah apakah pemilik masih mau menyerahkan tanahnya kepada petani penyakap tersebut untuk di garap kembali dengan ketentuan bagaimana cara kerja petani penyakap selama melakukan perjanjian dengan pemilik sebelumnya, baik atau tidaknya hasilnya ditentukan oleh pemilik tanah sawah.

Perjanjian Bagi Hasil pertanian baru dimulai setelah ada kesepakatan antara pemilik tanah dan petani penyakap. Dimana petani penyakap telah diijinkan untuk mengerjakan, mengusahakan dan menanami tanah yang bersangkutan dan telah ditentukan pula siapa yang harus menanggung biaya yang telah dikeluarkan, tetapi tidak menentukan mengenai berapa lama perjanjian yang berlangsung, sehingga perjanjian ini dapat berakhir sewaktu-waktu.

Mengenai jangka waktu perjanjian yang tidak disinggung oleh para pihak disebabkan karena berakhirnya atau selesainya perjanjian bagi hasil ini tergantung dari pemutusan perjanjian yang dilakukan oleh salah satu pihak yang bersangkutan setelah perjanjian tersebut berlansung berapa lama. Tetapi ditentukan bahwa hal ini harus dilakukan dengan cara kekeluargaan setelah panen selesai atau kemungkinan adanya kegagalan panen.

Menurut uraian diatas, dapat disimpulkan bahwa di Desa Krai Kecamatan Yosowilangun Kabupaten Lumajang masih terdapat sistem bagi hasil yang menggunakan Tradisonal. Walaupun terdapat banyak kekurangan dan bukan hanya satu pihak mengaku kerap menderita kerugian, namun keseluruhan responden (5 orang) berpendapat bahwa Perjanjian Bagi Hasil usaha pertanian di Desa Krai yang dilakukan menurut kebiasaan masih ingin mereka pertahankan karena aturan yang meraka lakukan selama ini khususnya sudah dari turun-temurun dan sebagian di antara mereka berpendapat bahwa Perjanjian Bagi Hasil yang dilakukan secara tradisional ini masih dapat di pertahankan.

\section{PENUTUP}

Berdasarkan hasil penelitian dan pembahasan mengenai sistem bagi hasil dan pemenuhan kebutuhan pokok buruh tani di Desa Krai Kecamatan Yosowilangun Kabupaten Lumajang dapat disimpulkan bahwa sistem bagi hasil masih bersifat tradisional dan sederhana. Sistem bagi hasil merupakan salah satu bentuk dari perjanjian tidak tertulis yang sifatnya cenderung seadanya sesuai 
dengan adat kebiasaan. Motif saling percaya merupakan hakekat dari perjanjian tersebut.

Bentuk perjanjian dari sistem bagi hasil dapat diistilahkan dengan istilah kedokan atau ngedok. Kedokan atau ngedok merupakan perjanjian tidak tertulis antara buruh tani penggarap sawah dengan petani pemilik sawah. pembagian hasil dari perjanjian tersebut berupa bawon dan pasrahan. Bawon merupakan bagian dari hasil panen yang diperoleh oleh buruh tani. Pasrahan merupakan bagian dari hasil panen yang diterima oleh pemilik sawah. adapun tugas yang harus diselesaikan oleh buruh tani penggarap sawah adalah aktivitas mulai penanaman hingga proses panen kecuali pemupukan. Sedangkan pemilik sawah bertugas menyiapkan lahan, pembibitan dan pemupukan saja. Risiko apabila terjadi gagal panen maka menjadi tanggung jawab bersama.

Berdasarkan hasil penelitian dan pembahasan dalam penelitian, maka saran untuk petani pemilik lahan dan petani penyakap agar tetap menjalin hubungan baik karena keduanya saling membutuhkan. Petani penyakap sebaiknya lebih mengoptimalkan dalam mengolah lahan petanian sehingga dapat memenuhi setoran bagi hasil yang harus disetorkan kepada pemilik lahan dan mendapatkan keuntungan. Petani penyakap harus lebih cermat dalam memilih system bagi hasil yang diterapkan sehingga dapat mengoptimalkan hasil yang akan didapat oleh petani penyakap.

\section{DAFTAR PUSTAKA}

Hanafie, R. 2010. Pengantar Ekonomi Pertanian. Yogyakarta: Andi Offset.

Maryati, S. 2000. Tata Laksana Makanan. Jakarta: PT Rineka Cipta.

Rahardjo. 2004. Pengantar Sosiologi Pedesaan dan Pertanian.Yogyakarta: Gadjah Mada University Press.

Sediaoetama, A. D. 2010. Ilmu Gizi. Jakarta: Dian Rakyat.

Soekirman. 2001, Dampak Pembangunan terhadap Keadaan Gizi Masyarakat. Majalah Gizi Indonesia.

Soelaeman, M. 2006. Ilmu Sosial Dasar "Teori dan Konsep Ilmu Sosial". Bandung: Refika Aditama.

Soetomo. 2013. Masalah Sosial dan Upaya pemecahannya. Yogyakarta: Pustaka Pelajar.

Sudarma, M. 2008. Sosiologi untuk Kesehatan. Jakarta: Salemba Medika.

Sudarto, T. 2003. Strategi Manajemen Rumah Tangga. Jember: Target Press.

Suhartono, S. 2009. Filsafat Pendidikan. Yogyakarta: Ar-Ruzz Media.

Sukirno, S. 2010. Makroekonomi Teori Pengantar. Jakarta: Raja Grafindo. 